Jurnal IImiah Iqra'

2541-2108 [Online] 1693-5705 [Print]

Tersedia online di: http://journal.iain-manado.ac.id/index.php/JII

\title{
Peran Keteladanan Pendidik dalam Perilaku Belajar Mahasiswa
}

\author{
Abdurrahman Wahid Abdullah \\ Fakultas Tarbiyah dan IImu Keguruan IAIN Manado \\ lakangur@gmail.com
}

\begin{abstract}
Abstrak
Dalam rangka mewujudkan tujuan pendidikan nasional, pihak penyelenggara pendidikan seharusnya tidak hanya memfokuskan perhatian pada hal-hal yang sifatnya fisik saja tetapi lebih daripada itu perlu ada perhatian yang lebih terhadap keteladanan yang merupakan hasil dari pemberian stimulus dan respon terhadap perilaku dosen. Metode yang digunakan penulis adalah metode analisis data deduktif dengan jenis penelitian kualitatif deskriptif. Hasil penelitian menyatakan bahwa keteladanan dosen sangat berperan dalam meningkatkan motivasi dan perilaku belajar mahasiswa. Kesimpulan tersebut diperoleh dari menganalisa konsep keteladanan dalam teori belajar behaviouristik dengan cara mengkorelasikannya dengan kajian tentang pemberian model atau contoh dari pendidik sehingga dapat mempengaruhi motif dan perilaku mahasiswa dalam belajar.
\end{abstract}

Kata kunci: Keteladanan Pendidik, Perilaku Belajar Mahasiswa.

\begin{abstract}
In order to realize the goals of national education, the organizers of education should not only focus on matters of a physical nature but more than that there needs to be more attention to the example that is the result of providing stimulus and response to the behavior of lecturers. The method used by the author is a method of deductive data analysis with a type of descriptive qualitative research. The results of the study stated that lecturer exemplary was very instrumental in increasing student motivation and learning behavior. The conclusion was obtained from analyzing the concept of exemplary in behaviouristic learning theory by correlating it with the study of giving models or examples from educators so that they can influence students' motives and behavior in learning.

Keywords: Exemplary Educator, Student Learning Behavior
\end{abstract}




\section{Pendahuluan}

Sejarah peradaban umat manusia mencatat bahwa pendidikan adalah alat yang vital dalam mempertahankan eksistensi seseorang, baik secara personal maupun secara struktural. Pendidikan merupakan salah satu upaya untuk mencegah manusia keluar dari hakikat kemanusiaan atau hakikat penciptaannya. Pendidikan dibutuhkan untuk menunjang peningkatan kualitas hidup seseorang sebagai manusia. Dengan pendidikan, setiap individu akan memperoleh pelajaran untuk menjadi seseorang yang memiliki karakter, kemampuan intelektualitas yang memadai, kepekaan emosi terhadap sekitar, dan spirit kemanusiaan dalam membangun pola interaksinya dengan sesama. Tanpa pendidikan, potensi yang ada pada diri manusia yang dibawanya sejak lahir tidak akan tergali dan berkembang.

Pentingnya pendidikan baik itu pendidikan formal, non formal maupun informal didukung oleh adanya regulasi yang khusus mengatur hal tersebut. Seperti halnya di Indonesia, tujuan pendidikan disebutkan secara langsung dalam pembukaan Undang-undang Dasar Tahun 1945 dan dijelaskan secara rinci dalam penjabarannya mulai dari tujuan pendidikan sejak manusia (bahkan) masih dalam kandungan, lahir, tumbuh besar, hingga dewasa. Ketika masih kecil, regulasi pendidikan sudah dituangkan dalam UU Nomor 20 Tahun 2003 Tentang Sistem Pendidikan Nasional dengan tujuan mengembangkan kepribadian dan potensi diri sesuai dengan tahap perkembangan peserta didik. Kemudian, tujuan pendidikan disebutkan lebih lanjut dalam Undang-Undang No. 20 Tahun 2003 dalam pasal 3

Pendidikan bertujuan untuk berkembangnya potensi peserta didik agar menjadi manusia yang beriman dan bertakwa kepada Tuhan Yang Maha Esa, berakhlak mulia, sehat, berilmu, cakap, kreatif, mandiri, dan menjadi warga negara yang demokratis serta bertanggung jawab.

Tujuan diselenggarakannya pendidikan yaitu untuk menciptakan manusia yang sejati, berpola fikir jernih dan berpola sikap santun. Pendidikan harus dilaksanakan secara merata dan menyeluruh karena tiap-tiap individu memiliki hak yang sama dalam memperoleh pendidikan. Kewajiban kepala negara dalam hal ini pemerintah untuk memastikan hal tersebut. Selain itu, di dalam aturan tentang Sistem Pendidikan Nasional juga disebutkan bahwa pendidikan merupakan usaha sadar dan terencana untuk mewujudkan suasana belajar dan proses pembelajaran agar peserta didik secara aktif dapat mengembangkan potensi dirinya untuk memiliki kekuatan spritual keagamaan, pengendalian diri, kepribadian, kecerdasan, akhlak mulia, serta keterampilan yang diperlukan dirinya, masyarakat, bangsa, dan 
negara. Sistem ini juga berisi tentang fungsi, tujuan, dasar-dasar pendidikan, hak-hak warga negara dalam pendidikan, dan lainnya, yang telah dirancang sedemikian rupa dan sistematis.

Sejak kemerdekaan, pada hakikatnya bangsa ini belum mengalami pertumbuhan yang signifikan ke arah yang diharapkan. Meski tidak dipungkiri bahwa telah banyak kemajuan di berbagai sektor. Namun jika menyorot pada tujuan pendidikan yang sejak dulu dirumuskan, hasilnya belum sampai pada kategori yang memuaskan. Padahal falsafah negara secara jelas menyatakan bahwa pendidikan diselenggarakan untuk mengembangkan potensi masyarakat agar menjadi manusia yang beriman dan bertakwa kepada Tuhan Yang Maha Esa, berakhlak mulia, sehat, berilmu, cakap, kreatif, mandiri, dan menjadi warga negara yang demokratis serta bertanggung jawab.

Jika melihat wajah dunia pendidikan yang ada di Indonesia pada saat ini, seseorang akan sampai kepada penilaian bahwa pendidikan yang ada di Indonesia cukup menjamin kualitas hidup bangsanya. Hal tersebut terlihat dari fasilitas lembaga pendidikan yang cukup mewah dan megah yang didirikan demi mencetak output manusia yang berkualitas dan unggul. Lembaga pendidikan tersebut tidak ragu menghabiskan tenaga, biaya, dan waktu semaksimal mungkin untuk melengkapi sarana pendukung dan memberikan fasilitas yang mumpuni. Namun jika dikaji dan dianalisis secara mendalam maka justru akan mulai terlihat persoalanpersoalan yang menjadi hambatan lahirnya keluaran dengan hasil memuaskan yang sesuai dengan visi lembaga pendidikan tersebut didirikan. Pelayanan pendidikan yang baik, yang telah dikonsepkan matang ke seluruh penjuru belum sepenuhnya dapat terealisasi. Masih ada narasi yang timbul ke permukaan, bahwa orientasi pemerintah sebagai konseptor sekaligus eksekutor program pelayanan pendidikan kepada masyarakat, hanya terpusat di beberapa titik saja. Program tersebut jarang menyentuh ke daerah pelosok. Ketidakmerataan pelayanaan pendidikan oleh pemerintah hanya merupakan salah satu sebab tidak terwujudnya agenda negara untuk mencerdaskan kehidupan bangsa namun juga terdapat sebab-sebab lain yang juga tak kalah urgen, seperti profesionalisme guru, keterbatasan fasilitas, krisis moral peserta didik, krisis keteladanan, dan lain-lain.

Maraknya kasus dalam dunia pendidikan yang viral, baik di dunia nyata maupun maya, seperti kasus perundungan atau bullying, pelecehan seksual, intimidasi, perbuatan mesum, kekerasan fisik, tindak pidana, dan sebagainya adalah bukti tidak terbantahkan yang menggambarkan kondisi pendidikan Indonesia yang 
justru mengalami kemuduran dari arah yang seharusnya. Kemajuan dari segi fisik nyatanya bukanlah segalanya. Lengkapnya fasilitas pendidikan dan megahnya bangunan sekolah-sekolah bukan satu-satunya faktor pendukung terwujudnya tujuan pendidikan. Menurut penulis, fokus utama pendidikan harus dikembalikan ke asalnya yaitu peningkatan mutu sumber daya pendidik dan tenaga pendidik untuk mendidik peserta didik baik dari aspek pola fikir maupun pola sikap.

"Guru kencing berdiri, siswa kencing berlari", adalah peribahasa yang tidak asing dalam dunia pendidikan. Semua orang mafhum bahwa yang dimaksud adalah peran pendidik yang diposisikan sebagai teladan dalam berkata dan juga dalam bersikap. Segala tindak- tanduk dan perilakunya adalah sesuatu yang juga dianggap sebagai pelajaran bagi peserta didik. Hal yang sama juga berlaku pada perguruan tinggi sebagai salah satu lembaga pendidikan. Pendidik yang dikenal dengan sebutan dosen memiliki tanggung jawab yang sangat besar dalam menentukan arah hasil pendidikan pada lembaga pendidikan tinggi. Tinggi-rendahnya kualitas mahasiswa sebagai output yang dihasilkan sangat ditentukan dari pola mendidik seorang dosen. Maka menjadi sebuah keharusan untuk mensyaratkan seseorang yang ingin menjadi pendidik atau dosen haruslah memiliki modal utama yaitu wawasan sebagai cerminan kemampuan intelektualitasnya dan juga budi luhur sebagai pantulan dari kematangan kecerdasan emosionalnya.

Peran seorang dosen sebagai pendidik pada lembaga pendidikan tinggi seharusnya tidak hanya sebatas pada proses belajar mengajar di dalam kelas atau terpenuhinya kuantitas tatap muka perkuliahan setiap semester, namun juga memberikan andil pada peningkatan motivasi belajar mahasiswa. Motivasi belajar mahasiswa adalah sesuatu yang ada dalam diri mahasiswa yang mendorong dan mengarahkan perilakunya kepada tujuan yang ingin dicapai dalam mengikuti program pendidikan pada perguruan tinggi. Tujuan tersebut tidak lain adalah menguasai bidang ilmu yang dipelajarinya sehingga dalam mengikuti proses perkuliahan, mahasiswa terdorong untuk menguasai materi perkuliahan tersebut dengan baik. Tujuannya bukan hanya untuk sekedar melulusi dan meraih beban bobot SKS maksimal semester selanjutnya. Perilaku dosen yang kesehariannya mempertontonkan aktivitas akademik guna mengasah intelektualisme seperti rajin membaca, aktif pada perkumpulan-perkumpulan diskusi, menghidupkan forum kajian ilmiah, dll akan memberikan pengaruh yang berarti kepada semangat, motivasi, dan perilaku belajar mahasiswa. 
Berdasarkan hal tersebut, penulis tertarik untuk mengkaji bagaimana keteladanan seorang pendidik bisa berperan terhadap tinggi-rendahnya motivasi belajar mahasiswa. Hal ini dikaitkan dengan teori belajar behaviouristik. Keteladanan dalam pendidikan selama ini kebanyakan hanya dibahas dalam tematema pembentukan karakter anak pada usia dini, namun dalam tulisan ini penulis berusaha menguraikan konsep keteladanan seorang pendidik dapat menjadi stimulus yang memotivasi dan meningkatkan perilaku belajar mahasiswanya.

\section{Kajian Teori}

Pemberian contoh perilaku yang baik atau keteladanan pendidikan adalah metode dipersepsikan sangat tinggi tingkat keberhasilannya dalam mempersiapkan dan membentuk sikap peserta didik, moral, spiritual dan sosial yang baik. Hal ini penting dilakukan karena orangtua dan guru atau dosen sebagai pendidik adalah contoh terbaik dalam pandangan seseorang yang akan ditiru melalui tingkahlakunya, sopan santunnya baik disadari atau tidak, bahkan hal tersebut secara langsung terpatri dalam jiwa dan perasaannya, untuk diikuti baik dalam ucapan maupun perbuatan (Abdullah Nasih Ulwan, 1999). Tulisan ini membahas dan mengkaji secara khusus keteladanan dari dosen merupakan sesuatu yang sangat dibutuhkan mahasiswa dalam mengembangkan potensi dan kualitas keilmuannya melalui pemberian contoh dan perilaku dalam rangka meningkatkan perilaku belajar mahasiswa. Pentingnya keteladanan dosen didasarkan kepada adanya kecenderungan mahasiswa untuk meniru dan mencontohi perbuatan dan perilaku orang yang dianggapnya lebih daripada dirinya, dikagumi serta dihormatinya.

\section{Keteladanan dalam Institusi Pendidikan Tinggi}

Salah satu metode yang dinilai paling ampuh dan efektif dalam pendidikan untuk mempersiapkan dan membentuk karakter peserta didik secara intelektual, spiritual, moral dan sosial adalah melalui keteladanan. Dalam mendidik seorang anak, selain menggunakan metode pemberian informasi, penjelasan, motivasi dan nasihat, pendidik dituntut untuk menanamkan nilai-nilai melalui perilaku untuk mengembangkan kepribadian peserta didik. Seorang pendidik adalah contoh ideal dalam pandangan anak, yang laku dan katanya perlu untuk digugu dan ditiru. Dengan keteladanan pendidik, penyelenggaraan pendidikan diperkirakan akan berhasil mencapai tujuan(Abdullah Nasih Ulwan, 1999). 
Keteladanan sangat terkait dengan bagaimana sikap terhadap kecenderungan seseorang dalam menerima atau menolak suatu objek penilaian yang dianggapnya baik atau tidak baik (Sanjaya, 2008). Pendidikan memberikan cara untuk menumbuhkan sikap dalam menerima atau menolak suatu objek. Disinilah peran pendidik sebagai penanggung jawab pendidikan anak secara formal untuk memberikan pemahaman dan cara bersikap yang benar dalam memandang suatu suatu objek. Penilaian terhadap suatu objek sebagai sesuatu yang bernilai atau tidak bernilai merupakan suatu kemampuan internal yang sangat berperan dalam proses pengambilan tindakan (action), terlebih apabila terbuka berbagai kemungkinan atau alternatif untuk bertindak. Pendidik mengambil peran yang sangat penting dalam hal ini, karena di samping menjadi pendamping dan pembimbing seorang peserta didik dalam memberikan nilai terhadap sebuah objek, dalam waktu yang sama dia juga berperan sebagai salah satu objek.

Keteladanan adalah proses asimilasi atau proses mencontoh. Melakukan peniruan atau mencontoh merupakan salah satu karakter peserta didik. Menurut Arief, dalam tahap awal proses pendidikan, pembiasaan merupakan cara yang sangat efektif dalam menanamkan nilai-nilai ke dalam jiwa seorang anak. Nilai-nilai yang tertanam dalam dirinya ini kemudian akan termanifestasikan dalam kehidupannya sejak ia mulai melangkah ke usia remaja dan dewasa (Arief, 2002). Jadi, penanaman nilai-nilai intelektualitas, spiritualitas, moralitas dan sosial sebenarnya tidaklah cukup hanya sampai pada pendidikan yang diterima seorang anak pada saat sekolah, tetapi juga seharusnya tetap diberikan pada saat dia beranjak dewasa. Dosen yang merupakan pendidik pada tingkat perguruan tinggi yang mengemban amanah tersebut. Bukan hanya sebagai pengarah dan pemberi penjelasan terhadap nilai-nilai, tetapi juga sekaligus sebagai tokoh yang diteladani. Sebagaimana yang dinyatakan Ulwan bahwa, "Figur sebagai teladan yang baik adalah yang sopan santunnya, tindak-tanduknya, disadari atau tidak akan ditiru anak didiknya" (A.N. Ulwan, 1992). Keteladanan merupakan metode influentif yang keberhasilannya paling dapat dipastikan memberikan pengaruh yang signifikan dalam pendidikan untuk membentuk dan mempersiapkan moral, spritual dan kecakapan sosial dan intelektual peserta didik.

Keteladanan pendidik dengan cara memberikan contoh baik yang untuk peserta didik adalah model dalam perkembangan pembelajaran anak didik karena segala tindak-tanduk, sopan-santun, cara berpakaian, dan tutur secara langsung bisa diamati dan ditiru oleh peserta didik. Hal yang ditiru itu adalah perilaku-perilaku 
yang diperagakan atau dilakukan oleh orang yang menjadi model. Dalam konsepnya, prinsip peniruan ini disebut dengan modeling. Modeling adalah proses peniruan seseorang terhadap orang lain yang menjadi idolanya atau orang yang dikagumi atau dihormatinya. Peniruan terhadap model biasanya dimulai dari rasa kagum. Seorang anak yang kagum terhadap kepintaran orang lain, misalnya terhadap guru atau dosen yang dianggapnya bisa melakukan segala sesuatu yang tidak bisa dilakukannya. Secara perlahan rasa kagum tersebut akan mempengaruhi emosinya dan secara perlahan pula ia akan meniru perilaku yang dilakukan oleh modelnya itu.

Pendapat Imam Ghazali- seorang intelek Islam, memberikan beberapa klasifikasi mengenai kompetensi yang sebaiknya dimiliki seorang pendidik. Pertama, pendidik harus mempunyai sifat kasih dan sayang terhadap peserta didik. Kedua, pendidik harus ikhlas dan rela menjalani pengabdiannya mendidik. Ketiga, pendidik harus senantiasa menasehati peserta didik. Keempat, pendidik harus senantiasa mengarahkan peserta didik ke arah yang positif. Kelima, pendidik harus mengenali dan mengetahui kemampuan kognitif peserta didiknya. Keenam, pendidik harus mampu memotivasi untuk menumbuhkan gairah belajar peserta didik. Ketujuh, pendidik harus mampu memilah dan memilih bahan ajar yang sesuai dengan tingkat pemahaman peserta didik. Dan kedelapan, pendidik harus senantiasa memberikan teladan yang baik (Ramayulis, 2002). Hal ini senada dengan dengan peraturan pemerintah Nomor 19 Tahun 2005 tentang Standar Pendidikan Nasional, yang menyatakan bahwa seorang pendidik diharuskan mengantongi beberapa kompetensi, diantaranya: profesional, pedagogis, kepribadian, dan sosial.

\section{Teori Belajar Behaviouristik}

Belajar adalah proses untuk mencapai berbagai macam kompetensi, keterampilan, dan sikap oleh manusia (Baharuddin \& Wahyuni, 2008). la merupakan suatu proses dimana manusia berusaha untuk merubah perilakunya sebagai akibat dari pengalaman (Dahar \& Willis, 2006). Belajar adalah hasil dari pengalaman, didalamnya terjadi stimulus-stimulus dan respon-respon. Maksudnya, manusia sejatinya belajar dari lingkungan (diluar dirinya) yang terinternalisasi melalui stimulus yang memunculkan respon-respon emosional dalam dirinya (Dahar \& Willis, 2006).

Belajar dapat dilakukan dalam berbagai macam cara. Salah satu yang paling utama adalah konsep belajar dengan jalan observasi yaitu seseorang belajar dengan 
cara mengamati orang lain. Belajar dengan menggunakan cara ini terkait dengan hubungan antara stimulus dan respons sehingga akhirnya dapat menghasilkan perubahan perilaku. Teori belajar ini adalah teori yang menekankan kepada perubahan perilaku peserta didik dan dikenal dengan nama teori belajar behavioristik. Jika dilihat dari pengertiannya teori belajar behavioristik merupakan suatu teori belajar secara psikologis yang berfokus pada perilaku nyata dan tidak terkait dengan hubungan kesadaran atau konstruksi mental. Oleh sebab itu seorang pendidik perlu memperhatikan dan mengamati model-model perilaku baik yang dibutuhkan peserta didiknya tak terkecuali dirinya sendiri.

Bagi pendidik yang menganut teori behaviorisme ini mengasumsikan bahwa tingkah laku peserta didik pada hakikatnya merupakan suatu respon terhadap lingkungan baik itu yang sudah berlalu maupun yang sedang berlangsung yang melingkupi semua tingkah laku yang diamati secara langsung oleh peserta didik merupakan pelajaran yang harus diikutinya (Djiwandono, 1989). Jadi, tugas utama seorang pendidik itu bukan hanya memberikan pengajaran melalui pemberian informasi dan penjelasan mengenai materi-materi sesuai dengan kurikulum, tetapi juga seorang pendidik diharapkan mampu menciptakan lingkungan belajar dan menjadi objek belajar pada diri peserta didik sehingga dapat memungkinkan terjadinya penguatan (reinforcement) bagi mereka.

Konsep behavioristik dalam pendidikan memandang bahwa perilaku individu sebagai peserta didik merupakan hasil belajar yang dapat diubah dengan memanipulasi atau mengkreasikan kondisi belajar yang didukung dengan berbagai penguatan (reinforcement) untuk mempertahankan perilaku atau hasil belajar sesuai dengan yang dikehendaki(Djiwandono, 1989). Hal tersebut muncul setelah manusia mengalami kontak dengan alam dan lingkungan sosialnya dalam proses pendidikan. Maka seorang individu akan menjadi lebih cerdas dan terampil tergantung kepada apakah ia berhasil atau tidak dalam belajar dengan lingkungannya. Sebagaimana yang dikatakan Mukminan

Aliran behavioristik yang lebih bersifat elementaristik memandang manusia sebagai organisme yang pasif, yang dikuasai oleh stimulus-stimulus yang ada di lingkungannya. Pada dasarnya, manusia dapat dimanipulasi, tingkah lakunya dapat dikontrol dengan jalan mengontrol stimulus-stimulus yang ada dalam lingkungannya (Mukminan, 1997). 
Teori behaviorisme yang menekankan adanya hubungan antara stimulus dengan respon secara umum dapat dikatakan memiliki arti yang sangat penting bagi peserta untuk mencapai keberhasilan belajar sebagaimana yang tertuang dalam tujuan pendidikan diselenggarakan. Hal tersebut dilakukan dengan cara; pendidik dalam memberikan pengajaran lebih banyak memberikan stimulus melalui strategi praktikum atau langsung pada perilaku keseharian. Dengan cara ini peserta didik akan memberi respon secara positif untuk meniru dan mengadaptasi perilaku tersebut. Lebih lanjut menurut Mukminan, terdapat beberapa prinsip tentang teori belajar behaviouristik:

1. Teori ini beranggapan bahwa belajar adalah proses perubahan tingkah laku. Maka seseorang dapat dikatakan telah mempelajari sesuatu jika yang bersangkutan dapat menunjukkan perubahan tingkah laku tentang hal yang dipelajarinya tersebut.

2. Teori ini beranggapan bahwa yang paling penting dalam belajar adalah adanya stimulus dan respon terhadap sesuatu. Karena kedua hal tersebut adalah hal yang dapat diamati.

3. Reinforcement, yaitu apa saja yang dapat menguatkan timbulnya respon. Hal ini merupakan faktor yang sangat penting dalam belajar. Respon akan semakin kuat apabila reinforcement (baik positif maupun negatif) ditambahkan (Mukminan, 1997).

Pendidikan adalah upaya mengembangkan perilaku peserta didik ke arah yang lebih baik. Pendidik berupaya agar dapat memahami peserta didik. Perkembangan perilaku merupakan objek pengamatan dari aliran-aliran behaviorisme. Perilaku dapat berupa sikap, ucapan, dan tindakan seseorang sehingga perilaku ini merupakan bagian dari psikologi secara umum dan secara khusus dibahas dalam teori belajar behaviouristik. Oleh sebab itu, teori belajar behavioristik yang mengkaji masalah stimulus dan respon dalam proses belajar adalah teori yang mendukung bahwa keteladanan yang dalam perilaku seorang pendidik adalah faktor yang mempengaruhi perilaku seseorang ataupun kelompok orang dalam proses belajar. 


\section{Minat, Motivasi, dan Perilaku Belajar Mahasiswa}

Dalam pembahasan ini, penulis tidak akan menguraikan bagaimana teori minat, motivasi dan perilaku belajar secara terperinci, namun akan mengkaji ketiga variabel tersebut secara integratif dan menyeluruh.

Minat adalah kecenderungan, gairah atau keinginan yang besar terhadap sesuatu atau untuk melakukan sesuatu. Dalam proses pendidikan khususnya pada perguruan tinggi, minat mempunyai pengaruh yang besar dalam belajar karena jika bahan atau materi perkuliahan yang akan dibahas tidak sesuai dengan minat mahasiswa, maka mahasiswa tersebut tidak akan belajar secara maksimal karena tidak ada daya tarik baginya. Sedangkan apabila bahan atau materi perkuliahan tersebut menarik minatnya, maka seorang mahasiswa akan dengan mudah dan tekun mempelajari karena ada dorongan dalam dirinya untuk belajar.

Salah satu faktor yang mempengaruhi minat seseorang adalah adanya motivasi. Motivasi merupakan dorongan internal maupun eksternal yang menimbulkan hasrat dan minat yang mendorong untuk melakukan sebuah kegiatan dalam mencapai tujuan tertentu. Dalam ilmu pendidikan dikenal dengan istilah motivating force, yakni kekuatan yang mendorong siswa atau mahasiswa untuk belajar. Mahasiswa yang mempunyai minat terhadap perkuliahan akan terdorong untuk giat belajar, berbeda dengan mahasiswa yang menghadiri perkuliahan hanya dengan motif mengisi absensi saja. Oleh sebab itu, motivasi sangat dibutuhkan dalam proses belajar mengajar. Motivasi adalah faktor yang sangat kuat untuk dapat memacu pengembangan potensi diri mahasiswa dalam menggali potensi, pengetahuan dan keterampilan secara mandiri sesuai dengan kompetensi yang diharapkan.

Secara umum, terdapat 2 faktor yang membuat seseorang dapat termotivasi untuk belajar, yaitu:

1. Motivasi belajar yang berasal dari faktor internal.

Motivasi ini diperoleh dari kesadaran diri atas pemahaman tentang arti betapa pentingnya belajar untuk mengembangkan potensi dari dalam diri dalam rangka meningkatkan kualitas kehidupan; dan

2. Motivasi belajar dari faktor eksternal.

Motivasi ini dapat berupa rangsangan dari orang lain, atau lingkungan sekitar yang dapat mempengaruhi orang yang bersangkutan secara psikologis. 
Secara khusus, faktor-faktor yang mempengaruhi motivasi belajar seorang mahasiswa adalah minat terhadap konsentrasi bidang ilmu yang dipelajarinya, orientasi dalam melanjutkan studi pada perguruan tinggi, kualitas dosen, metode atau strategi perkuliahan yang digunakan oleh dosen, kondisi dan suasana ruang kuliah, fasilitas belajar yang dapat dimanfaatkan oleh mahasiswa, dll. Motivasi belajar mahasiswa merupakan dorongan semangat yang menggerakkan perilaku belajar mahasiswa. Perilaku belajar dalam psikologi pendidikan diartikan sebagai suatu proses usaha yang dilakukan seseorang untuk memperoleh perubahan perilaku yang baru secara keseluruhan sebagai hasil pengalaman individu itu sendiri dalam berinteraksi dengan lingkungannya (Yudhawati \& Haryanto, 2012). Perilaku belajar pada umumnya dimanifestasikan atau diwujudkan dalam bentuk kebiasaan, keterampilan, pengamatan, berpikir asosiatif dan daya ingat, berpikir rasional dan kritis, sikap inhibisi, apresiasi, dan tingkah laku afektif (Syah, 2002). Perilaku belajar dapat dilihat dari adanya perubahan tingkah laku dalam kegiatan belajar karena belajar merupakan suatu perubahan yang nampak terjadi di dalam diri seseorang disebabkan oleh pengalaman yang bisa mempengaruhi tingkah laku orang tersebut.

Pada pembahasan sebelumnya, telah dipaparkan bahwa belajar pada dasarnya adalah suatu proses aktivitas atau kegiatan seseorang dalam berinteraksi dengan lingkungannya sehingga menghasilkan perubahan tingkah laku yang bersifat positif baik perubahan dalam aspek pengetahuan, sikap maupun psikomotorik (Sanjaya, 2009). Perilaku belajar berkaitan dengan perubahan tingkah laku karena setiap perubahan tingkah laku seseorang dalam proses belajar disebabkan oleh pengalaman yang dialami secara berulang-ulang. Perubahan dalam tingkah laku itu bisa mengarah pada perilaku yang baik dalam proses belajar, akan tetapi tetap ada kemungkinan yang mengarah pada tingkah laku yang negatif dalam proses belajar. Hal ini berarti berhasil atau tidaknya pencapaian tujuan pendidikan itu sangat bergantung kepada proses belajar yang dialami peserta didik, baik ketika berada di sekolah maupun di lingkungan rumah atau keluarganya sendiri (Syah, 2002).

Peranan dosen sebagai pendidik yang juga merupakan role model memiliki kontribusi yang sangat besar dalam peningkatan motivasi dan perkembangan perilaku belajar seorang mahasiswa. Dosen yang disiplin, menguasai materi dan selalu membimbing serta mendukung pengembangan potensi mahasiswa, menghidupkan suasana akademis melalui pengkajian atau ruang-ruang diskusi baik secara formal maupun non-formal, menumbuhkan semangat intelektualitas di 
tengah-tengah mahasiswa dipastikan akan dapat meningkatkan motivasi dan perilaku belajar mereka.

\section{Kesimpulan}

Berdasarkan uraian pada pembahasan dapat disimpulkan isi tulisan ini sebagai berikut:

Dalam rangka mewujudkan tujuan pendidikan, sebuah lembaga pendidikan khususnya lembaga perguruan tinggi seharusnya tidak hanya fokus pada peningkatan fasilitas ruang-ruang kuliah, strategi pembelajaran atau kurikulum saja tetapi juga perlu ada perhatian yang lebih terhadap lingkungan belajar. Keteladanan yang merupakan hasil dari pemberian stimulus dan respon terhadap perilaku dosen sehari-hari dapat mempengaruhi perilaku mahasiswanya. Semakin dosen memberikan contoh yang baik kepada mahasiswanya, maka akan semakin besar juga peluang mahasiswa berperilaku baik. Termasuk dalam hal motivasi belajar, semakin seorang dosen meneladankan perilaku yang mencerminkan tingginya semangat cinta terhadap ilmu, maka dipersepsikan akan semakin meningkat pula motivasi serta perilaku belajar seorang mahasiswa. Oleh karena itu, keteladanan melalui sikap dan perilaku diharapkan bisa lebih menjadi perhatian seorang dosen guna meningkatkan motivasi dan perilaku belajar mahasiswanya agar tujuan pendidikan dapat diwujudkan secara ideal dan optimal.

\section{Referensi}

Arief, A. (2002). Pengantar Ilmu dan Metodologi Pendidikan Islam. Jakarta: Ciputat Pers.

Baharuddin, J., \& Wahyuni. (2008). Teori Belajar dan Pembelajaran. Yogyakarta: Ar Ruz Media.

Dahar, \& Willis, R. (2006). Teori-teori Belajar dan Pembelajaran. Jakarta: Erlangga.

Djiwandono, S. E. W. (1989). Psikologi Pendidikan. Jakarta: Departemen Pendidikan dan Kebudayaan.

Mukminan. (1997). Teori Belajar dan Pembelajaran. Yogyakarta: P3G IKIP.

Ramayulis, H. (2002). Ilmu Pendidikan Islam. Jakarta: Alam Mulia.

Sanjaya, W. (2008). Strategi Pembelajaran: Berorientasi Standar Proses Pendidikan. Jakarta: Kencana Prenada Media Group.

Sanjaya, W. (2009). Kurikulum dan Pembelajaran. Jakarta: Kencana. 
Syah, M. (2002). Psikologi Pendidikan dengan Pendekatan Baru. Bandung: PT Remaja Rosdakarya.

Ulwan, A.N. (1992). Pendidikan Anak Menurut Islam: Kaidah-kaidah Dasar. Bandung: PT Remaja Rosdakarya.

Ulwan, Abdullah Nasih. (1999). Pedoman Pendidikan Anak dalam Islam. (S. Kamalia \& H. N. Ali, Eds.). Jakarta: Pustaka Asy-Syifa.

Yudhawati, R., \& Haryanto, D. (2012). Teori-teori Dasar Psikologi Pendidikan. Jakarta: Prestasi Pustaka. 